Check for updates

Cite this: New J. Chem., 2020, 44, 16246

DOI: 10.1039/d0nj90128h

rsc.li/njc

\section{Correction: Bacterial biosynthesis of nanosilver: a green catalyst for the synthesis of (amino pyrazolo)-(phenyl)methyl naphth-2-ol derivatives and their antimicrobial potential}

\author{
Ganji Praveena, $^{\text {ab }}$ Swetha Yagnam, ${ }^{\text {bc }}$ Linga Banoth, $^{\text {ab }}$ Rajiv Trivedi*bc $^{\text {be }}$ ( \\ Reddy Shetty Prakashamªb
}

Correction for 'Bacterial biosynthesis of nanosilver: a green catalyst for the synthesis of (amino pyrazolo)-(phenyl)methyl naphth-2-ol derivatives and their antimicrobial potential' by Ganji Praveena et al., New J. Chem., 2020, 44, 13046-13061, DOI: 10.1039/D0NJ01924K.

The authors regret that affiliation b was incorrect in the original article. The correct affiliation is as shown above.

The Royal Society of Chemistry apologises for these errors and any consequent inconvenience to authors and readers.

\footnotetext{
${ }^{a}$ Organic Synthesis and Process Chemistry, CSIR-Indian Institute of Chemical Technology, Hyderabad 500007, Telangana, India. E-mail: prakasam.iict@gov.in

${ }^{b}$ Academy of Scientific and Innovative Research, Ghaziabad, Uttar Pradesh, 201002, India

${ }^{c}$ Catalysis and Fine Chemicals Division, CSIR-Indian Institute of Chemical Technology, Uppal Road, Tarnaka, Hyderabad 500007, Telangana, India.

E-mail: trivedi@iict.res.in, trivedi.iict@gov.in
} 